\title{
Latex Micro Diagnosis, Modern Management Tool of Rubber Plantations of Clones With Active or Rapid Metabolism IRCA 18, IRCA 130, PB 235, PB 260 and PB 330
}

\section{Adou Bini Yao Christophe}

Université Nangui Abrogoua, UFR Sciences de la Nature, Laboratoire de

Biologie et Amélioration des Productions Végétales, Abidjan,

Côte d'Ivoire

\section{Okoma Koffi Mathurin}

Centre National de Recherche Agronomique (CNRA), Laboratoire

Central de Biotechnologie, Abidjan, Côte d'Ivoire

\section{Obouayeba Abba Pacôme}

Université Jean Lorougnon, UFR Agroforesterie, Laboratoire de

Biochimie, Daloa, Côte d'Ivoire

Atsin Guy Joël Olivier

Centre National de Recherche Agronomique (CNRA), station de Recherche de Bimbresso, Abidjan, Côte d'Ivoire

\section{Ballo Espérence Kouadio}

Université Jean Lorougnon, UFR Agroforesterie, Laboratoire de

Physiologie et Pathologie Végétale, Daloa, Côte d'Ivoire

Essehi Jean-Lopez

Université Félix Houphouët-Boigny, UFR des Sciences de la Terre et des ressources Minières, Laboratoire de Pédologie, Abidjan, Abidjan,

Côte d'Ivoire

\section{Wahounou Polié Jean}

Centre National de Recherche Agronomique (CNRA), station de

Recherche de Bimbresso, Abidjan, Côte d'Ivoire

\section{Soumahin Eric Francis}

Université Jean Lorougnon, UFR Agroforesterie, Laboratoire de Physiologie et Pathologie Végétale, Daloa, Côte d'Ivoire

\section{Kouakou Tanoh Hilaire}

Université Nangui Abrogoua, UFR Sciences de la Nature, Laboratoire de

Biologie et Amélioration des Productions Végétales, Abidjan,

Côte d'Ivoire 


\title{
Obouayeba Samuel
}

Centre National de Recherche Agronomique (CNRA), station de Recherche de Bimbresso, Abidjan, Côte d'Ivoire

\section{Doi: 10.19044/esj.2018.v14n3p385 URL:http://dx.doi.org/10.19044/esj.2018.v14n3p385}

\begin{abstract}
The cultivated rubber clones are sensitive to latex harvesting regimes according to their laticiferous metabolism. Thus, in order to determine the best latex harvesting systems of clones with active or rapid metabolism (IRCA 18, IRCA 130, PB 235, PB 260 and PB 330), six latex harvesting technologies are applied to them in a bulk statistical device from Fisher to four rehearsals. The rubber is tapped in downward half spiral stimulated or not for nine years after the opening of the tapping panel. The agronomic parameters (production, vegetative growth), the tapping panel dryness and those of the latex micro diagnosis were evaluated. The results indicate that these clones independently of the latex harvesting system have good rubber productivity $\left(2310 \mathrm{~kg}^{-} \mathrm{ha}^{-1} \cdot \mathrm{y}^{-}\right.$ $\left.{ }^{1}\right)$ with good radial vegetative growth $\left(2.9 \mathrm{~cm} \cdot \mathrm{y}^{-1}\right)$. Their trees show a wellbalanced physiological profile and an acceptable sensitivity to the tapping panel dryness (4.9\%). However, the physiological index, the bark consumption and the sensitivity to the tapping panel dryness lead to retain the latex harvesting technologies " $\mathrm{S} / 2 \mathrm{~d} 36 \mathrm{~d} / 7 \mathrm{~Pa}(1)$ ET2.5\% 4/y and $\mathrm{S} / 2 \mathrm{~d} 46 \mathrm{~d} / 7$ Pa1(1) ET $2.5 \% 4 / y$ " for the best. This index, favorably influencing the choice of technologies adapted to clones with active metabolism, contributes to the modern and efficient management of a rubber plantation.
\end{abstract}

Keywords: Hevea brasiliensis, latex harvesting technology, clones with active or rapid metabolism, physiological parameters, Côte d'Ivoire

\section{Introduction}

The production of rubber from a rubber plantation inevitably results from tapping (Serres et al. 1994; Obouayeba et al. 2000). It is obtained from an incision of the tissues of the trunk bark (Gomez, 1982; Thomas et al. 1995; Obouayeba et al. 2000). As a result of this incision, the laticiferous vessels, which are specialized tissues, with special rubber-producing cells (laticiferous), are severed leaving the latex (Gomez, 1982) from which the natural rubber is extracted (Obouayeba et al. 2000). Although tapping of rubber trees allows to produce rubber, but this production is limited (Traoré et al. 2014) because, tapping alone can not better enhance the potential production of different rubber clones (Jacob et al., 1988). (Jacob et al. 1988). These potentialities are indeed dependent on the metabolic function of the laticiferous cell of these clones (D'Auzac et al. 1989; Serres et al. 1994). To 
address these concerns, nowadays and in a systematic way, the hormonal stimulation of rubber production (Obouayeba, 1995 and 2009; Soumahin, 2010) is added to the tapping system. It consists in applying to the tree a stimulating paste with an active ingredient concentration (Ethephon) ranging from 2.5 to $5 \%$ in order to improve its rubber productivity (Obouayeba, 1993; Traoré et al., 2014). Latex harvesting systems improve the rubber productivity of plantations (Jacob et al. 1990). This productivity is also a function of the intensity of the applied latex harvesting system and the metabolic class of the tapped clone (Dian, 1997). The practice of tapping or a tapping system (Obouayeba, 1995 and 2009) and/or a strategy of hormonal stimulation of rubber production can constitute a system or technology for harvesting latex that is more or less intensive for a given clone.

However, it is known that the most efficient latex harvesting technologies in rubber production weaken the physiological state of the trees. Thus, in order to sustain and even raise the productivity of hevea, many important studies have been carried out in the field of plant physiology and latex (Jacob et al. 1988). This work has made it possible to group clones currently cultivated into three classes of metabolic activity and to establish a clonal typology of the metabolic functioning of the laticiferous system (Eschbach et al. 1984; Jacob et al. 1988; Serres et al. 1994; Jacob et al. 1995; Gohet et al. 1996). The latter is based on the response to the hormonal stimulation of rubber production of the groups of clones concerned. Given the heavy investment in rubber production and the late return on investment, the management of a plantation must be modern through the use of the Latex Micro Diagnosis (LMD) in order to make the rubber production activities profitable during a long term. This requires the implementation of efficient latex harvesting technologies adapted to laticiferous metabolisms of clones.For this purpose, the physiological profile of the rubber obtained from the four parameters of the Latex Micro Diagnosis (LMD) of fast metabolism clones (PB 235, PB 260, PB 330, IRCA 18 and IRCA 130) subjected to six (6) of the latex harvesting technologies is analyzed to determine the best.

\section{Material and Methods \\ Plant Materials}

The plant material is composed by clones IRCA18, IRCA 130, PB 235, PB 260 and PB 330, described as follows:

- IRCA18, (Institut de Recherche sur le Caoutchouc), developped in Côte d'Ivoire, is a progeny of PB 5/51 $\times$ RRIM 605. The latex diagnosis highlights a very active metabolism, easy flow but low sucrose reserves. This clone needs little stimulation. It has a very fast rise in production. It is sensitive to wind, and very sensitive to tapping panel dryness (Obouayeba et al. 2000). It is also strongly attacked by Corynespora cassiicola causing leaf fall; 
- $\quad$ IRCA 130 is from Côte d'Ivoire and is a cross between PB 5/51 $\times$ IR 22. More vigorous than the clone GT 1 (Gondang Tappen), and is opened at five years. Its rubber yield is at the same level as that of clone PB 235 (Prang Besar) for the first three years of tapping. Its physiological profile is favorable to productivity over the long term although its rubber production input is very fast. The risk of dry trees of this clone is considered low given the favorable physiological profile;

- $\quad$ Clone PB 330 (Prang Besar), originating in Malaysia, originates from the cross between PB 5/51 and PB 32/36. Planted for the first time in LSCF in Côte d'Ivoire in 1989. It has characteristics very similar to those of clone PB 255 (clone with rapid or very active metabolism). This clone has rapid growth in height and secondary branches that are light and spread along the axis. It has a sensitivity to breakage due to wind (Chapuset, 2001);

- $\quad$ PB 235 clone is from Malaysia (Prang Besar), and is a cross between $\mathrm{PB} 5 / 51 \times \mathrm{PB}$ S/78. The virgin bark is smooth, fairly thick and tender. It poses no particular problem in bleeding. The renewed bark is sometimes bulging. Clone trees are very vigorous (Obouayeba \& Boa, 1993; Obouayebaet al. 2000; Obouayeba, 2005) and, therefore, is working an average of four and a half years. Clone growth is very homogeneous. So a year after opening, $95 \%$ of trees are being bled. The metabolism of this clone is very active. The sugar levels are still relatively low and protective systems, which involves using very sparingly stimulation;

- $\quad$ The clone PB 260 is bred in Malaysia (Prang Besar) and is a progeny of PB 5/51 × PB 49. It is a ''quick starter', with a very active metabolism. It grows vigourously during tapping. Tapping actives its laticiferous metabolism and it needs few stimulations when reducing the tapping frequency. Its intralaticiferous sugar content is low when tapped and it couldn't afford to be too much stimulated. It is highly sensitive to tapping panel dryness (Obouayeba et al. 2000).

\section{Experimental Design}

The trees of those different clones were planted at the density of 510 trees per ha $(7 \mathrm{~m} \times 2.8 \mathrm{~m})$ since 1988 in straight lines. RCB (Randomized Complete Blocs) of 6 treatments in 4 replicates were used as experimental design with around 100 trees per plot.

The test covers an average area of 4.7 ha. This trial was set up on the Gô research station in south-western Côte d'Ivoire.

The experiments was started in April 1996 at the opening of the trees at $1.20 \mathrm{~m}$ above the ground and were completed in March 2005 for the clone PB 330; from April 1998 to March 2007 for the clone IRCA 130; from October 1994 to September 2003 for the clone IRCA 18; from March 1995 to 
February2004 for the clone PB 235 and from April 1997 to March 2006 for the clone PB 260.

\section{Treatments}

The trees were opened at height of $1.20 \mathrm{~m}$ (panel BO-1). The latex harvesting technologies applied are shown in Table $\mathbf{1 .}$

\section{Tapping}

Two tappers were used. One for the tapping of trees in the first blocs $\mathrm{A}$ and $\mathrm{B}$ and the second for the others two blocs C and D. Averages consumptions of bark (perpendicular to the tapping cut) were:

- $\quad \mathrm{d} 2: 1.0$ to $1.3 \mathrm{~mm} /$ tapping, 156 tapping per years (156 to $203 \mathrm{~mm} / \mathrm{y}$ )

- $\quad \mathrm{d} 3$ : 1.3 to $1.5 \mathrm{~mm} /$ tapping, 104 tapping per years (135 to $156 \mathrm{~mm} / \mathrm{y}$ )

- $\quad \mathrm{d} 4: 1.5$ to $1.8 \mathrm{~mm} /$ tapping, 78 tapping per years (117 to $140 \mathrm{~mm} / \mathrm{y})$

- $\quad \mathrm{d} 5: 1.7$ to $2.0 \mathrm{~mm} /$ tapping, 65 tapping per years $(110$ to $130 \mathrm{~mm} / \mathrm{y}$ )

- $\quad \mathrm{d} 6: 1.8$ to $2.0 \mathrm{~mm} /$ tapping, 52 tapping per years (93 to $104 \mathrm{~mm} / \mathrm{y}$ )

\section{Hormonal Stimulation}

All selected trees were stimulated on the tapping panel, on a $1 \mathrm{~cm}$ wide band, due to $1 \mathrm{~g}$ of stimulant per tree (Obouayeba, 1993; Traore et al., 2014). The stimulating product used is obtained by mixing Ethrel and palm oil. Ethrel contains $2.5 \%$ of active ingredient which is 2-chloroethylphosphonic acid or Ethephon (CEPA).

\section{Production of Rubber}

Rubber production of each treatment was weighed every 4 weeks using a scale. Samples of fresh rubber were collected for each treatment to determine the coefficient of transformation (CT) which was used to calculate the production of dry rubber expressed in kilograms per hectare per year $\left(\mathrm{kg}^{-\mathrm{ha}^{-}}\right.$ $\left.{ }^{1} \cdot \mathrm{y}^{-1}\right)$.

\section{Production of Rubber}

Rubber production of each treatment was weighed every 4 weeks using a scale. Samples of fresh rubber were collected for each treatment to determine the coefficient of transformation (CT) which was used to calculate the production of dry rubber expressed in kilograms per hectare per year $\left(\mathrm{kg}^{-h^{-}}\right.$ $\left.{ }^{1} \cdot \mathrm{y}^{-1}\right)$.

Table 1: Treatments applied in downward tapping of clones PB 235, IRCA 18, IRCA 130,

PB 260 and PB 330 during nine years of experimentation in southwestern Cote d'Ivoire

\begin{tabular}{lccc}
\hline $\mathrm{N}^{\circ}$ & Treatments & TI & Description \\
& $(\%)$ & \\
\hline
\end{tabular}




\begin{tabular}{|c|c|c|c|}
\hline 1 & $\begin{array}{l}\mathrm{S} / 2 \mathrm{~d} 26 \mathrm{~d} / 7 \text {, nil } \\
\text { stimulation }\end{array}$ & 100 & $\begin{array}{l}\text { Half spiral cut tapped at alternate daily frequency } \\
\text {,six day in tapping followed by one day rest, not } \\
\text { stimulated }\end{array}$ \\
\hline 2 & $\begin{array}{c}\mathrm{S} / 2 \mathrm{~d} 3 \mathrm{6d} / 7 \mathrm{ET} 2.5 \% \\
\mathrm{~Pa} 1(1) 4 / \mathrm{y}\end{array}$ & 67 & $\begin{array}{l}\text { Half spiral cut tapped at third daily frequency, six } \\
\text { day in tapping followed by one day; stimulated with } \\
\text { Ethephon of } 2.5 \% \text { active ingredient with } 1 \mathrm{~g} \text { of } \\
\text { stimulant applied on panel on a } 1 \mathrm{~cm} \text { band, } 4 \\
\text { applications per year. }\end{array}$ \\
\hline 3 & $\begin{array}{c}\mathrm{S} / 2 \mathrm{~d} 4 \mathrm{6d} / 7 \mathrm{ET} 2.5 \% \\
\mathrm{~Pa} 1(1) 4 / \mathrm{y}\end{array}$ & 50 & $\begin{array}{l}\text { Half spiral cut tapped at fourth daily frequency, six } \\
\text { day in tapping followed by one day; stimulated with } \\
\text { Ethephon of } 2.5 \% \text { active ingredient with } 1 \mathrm{~g} \text { of } \\
\text { stimulant applied on panel on a } 1 \mathrm{~cm} \text { band, } 4 \\
\text { applications per year. }\end{array}$ \\
\hline 4 & $\begin{array}{c}\mathrm{S} / 2 \mathrm{~d} 4 \mathrm{6d} / 7 \mathrm{ET} 2.5 \% \\
\mathrm{~Pa} 1(1) 8 / \mathrm{y}\end{array}$ & 50 & $\begin{array}{l}\text { Half spiral cut tapped at fourth daily frequency, six } \\
\text { day in tapping followed by one day; stimulated with } \\
\text { Ethephon of } 2.5 \% \text { active ingredient with } 1 \mathrm{~g} \text { of } \\
\text { stimulant applied on panel on a } 1 \mathrm{~cm} \text { band, } 8 \\
\text { applications per year. }\end{array}$ \\
\hline 5 & $\begin{array}{c}\mathrm{S} / 2 \mathrm{~d} 5 \text { 6d/7 ET2.5\% } \\
\mathrm{Pa} 1(1) 8 / \mathrm{y}\end{array}$ & 40 & $\begin{array}{l}\text { Half spiral cut tapped at fifth daily frequency, six } \\
\text { day in tapping followed by one day; stimulated with } \\
\text { Ethephon of } 2.5 \% \text { active ingredient with } 1 \mathrm{~g} \text { of } \\
\text { stimulant applied on panel on a } 1 \mathrm{~cm} \text { band, } 8 \\
\text { applications per year. }\end{array}$ \\
\hline 6 & $\begin{array}{c}\mathrm{S} / 2 \mathrm{~d} 6 \text { 6d/7 ET2.5\% } \\
\mathrm{Pa}(1) \text { 10/y }\end{array}$ & 33 & $\begin{array}{l}\text { Half spiral cut tapped at sixth daily frequency, six } \\
\text { day in tapping followed by one day; stimulated with } \\
\text { Ethephon of } 2.5 \% \text { active ingredient with } 1 \mathrm{~g} \text { of } \\
\text { stimulant applied on panel on a } 1 \mathrm{~cm} \text { band, } 10 \\
\text { applications per year. }\end{array}$ \\
\hline
\end{tabular}

TI: Tapping Intensity

\section{Radial Vegetative Growth}

The circumferences of trees were measured annually in April (opening trees in April 1996) for clone PB 330, April (opening trees in April 1998) for the clone IRCA 130; October (opening trees in October 1994) for the clone IRCA 18; March (opening trees in March 1995) for the clone PB 235 and April (opening of trees in April 1997) for the clone PB 260. The measurements were made at the height of $1.70 \mathrm{~m}$ above the ground using a measuring tape.

\section{Rates of Tapping panel Dryness}

On certain trees, during tapping, the flow of latex is abnormally weak or even nonexistent; a more or less important part of the cut does not produce latex. This is called symptom of tapping panel dryness. The tapping panel dryness quick measurement method by visual estimation enables to report on the progress of the "disease". On that respect, the trees tapped were rated from 0 to 6 in proportion to the progress of the disease according to the code " 0 " 
(healthy cut, normal flow all along the tapping cut) and " 6 " (completely dry cut).

\section{Latex Micro Diagnosis}

From the latex sampled, it was possible to determine annually, by the Latex Micro Diagnosis (LMD) method, the levels of dry rubber content (ExS) and the contents of sucrose (Sac), inorganic phosphorus (Pi) and thiol groups (R-SH) of the latex. The dry rubber content was determined according to the method described by Eschbach et al. (1984), while the contents of sucrose, inorganic phosphorus and thiol groups were obtained respectively by Ashwel (1957), Taussky \& Shorr (1953) and Boyne \& Ellman (1972). The LMD data were analyzed on the basis of the reference values established by Jacob et al. (1987) and interpreted according to the Roussel interpretation scheme (Jacob et al. 1987).

\section{Physiological Index}

Physiological studies have shown the strong involvement of few physiological parameters in the production of rubber (Jacob et al. 1985) and, consequently, allowed the prediction of rubber production (Koffi et al. 2004). The influence of these physiological parameters on the production of rubber could vary from one technology of harvesting the latex to another. Thus, we define the physiological index as the product of the average concentrations of Sucrose (Sac), Inorganic Phosphorus (Pi) and Thiol groups (R-SH) at a given time. We believe, with this physiological index, to better discriminate the latex harvesting systems applied to rubber trees.

\section{Determination of Better Latex Harvesting Systems}

In order to determine the best latex harvesting systems, the physiological parameters focused on the latex micro diagnosis (dry rubber content, sucrose, inorganic phosphorus and thiol groups) and those of production, isodiametric growth and tapping panel dryness sensitivity have been put to use. The mean values of these parameters were subjected to an analysis of variance. This made it possible to classify the different latex harvesting technologies according to their effect on the parameters studied. The best technologies for latex harvesting were those that have produced both:

$>\quad$ A high level of rubber production;

$>\quad$ Low impact on isodiametric growth;

$>\quad$ Low sensitivity to the tapping panel dryness, expressed by low percentages of LEM;

$>\quad$ A good physiological profile with a dry rubber content, sucrose, inorganic phosphorus and thiol compounds ranging from medium to high. 


\section{Statistical Analysis}

An analysis of variance of the data including the rubber yield, vegetative radial growth, latex micro diagnostic and tapping panel dryness was done with the SAS statistical software and the Student-Newman-Keuls test, at $\mathrm{P}<0.05$.

\section{Results and Discussion}

Influence of Latex Harvesting Technologies on the Annual Average Dry Rubber Production of Clones PB 235, IRCA 18, IRCA 130, PB 260 and PB 330

Clone $P B$ 235. The dry rubber production expressed in $\mathrm{kg} \cdot \mathrm{ha}^{-1} \cdot \mathrm{y}^{-1}$ did not significantly vary regardless of the latex harvesting technology (Table 2). Overall, this production of dry rubber seems to decrease with the reduction in tapping frequency. The increase in stimulation frequency did not have a significant effect on production when tapping was performed every 4 days (treatments 3 and 4). Similarly, the passage of tapping frequencies every 4 days to every 5 days (treatments 4 and 5) for the same stimulation frequency (8/y) did not have a significant impact on the production of rubber dry.

Clone IRCA 18. Dry rubber production expressed in $\mathrm{kg} \cdot \mathrm{ha}^{-1} \cdot \mathrm{an}^{-1} \mathrm{did}$ not distinguish latex harvesting technologies (Table 2). Treatment 2 (d3-4/y), with $67 \%$ tapping intensity, was the highest $\left(2730 \mathrm{~kg} \cdot \mathrm{ha}^{-1} \cdot \mathrm{y}^{-1}\right)$. It is statistically identical to those of the other treatments except for treatment 6 (d6-10/y), which is statistically the lowest $\left(2252 \mathrm{~kg} \cdot \mathrm{ha}^{-1} \cdot \mathrm{y}^{-1}\right)$. Average annual dry rubber production per hectare (tapping downward), with all latex harvesting technologies, reached $2238 \mathrm{~kg}$. This production does not appear to be related to latex harvesting technologies applied to trees. Overall, it appears to decrease with decreased frequency of tapping.

Clone IRCA 130. The production of rubber expressed in $\mathrm{kg} \cdot \mathrm{ha}^{-1} \cdot \mathrm{y}^{-1} \mathrm{did}$ not significantly vary regardless of the latex harvesting technology (Table 2). This production of rubber seems to decrease with the reduction in the frequency of tapping. The increase in stimulation frequency did not have a significant effect on production when tapping was performed every 4 days (treatments 3 and 4). Similarly, the variation of tapping frequencies of 4 days to 5 days (treatments 4 and 5) for the same stimulation frequency (8/y) did not have a significant impact on production.

Clone PB 260. The yield of rubber from treatment $2(\mathrm{~d} 3-4 / \mathrm{y})$, at $67 \%$ bleeding intensity, was highest (2829 kg.ha-1.y ${ }^{-1}$ ) (Table 2). This is statistically identical to that of the other treatments, except that of treatment 6 (d6-10/y) which is statistically the lowest (2359 kg.ha- $\left.\mathrm{ha}^{-1}\right)$.Average annual dry rubber production per hectare (tapping downward), with all latex harvesting technologies, reached $2662 \mathrm{~kg}$. This production does not appear to be related to latex harvesting technologies applied to trees. This production of 
rubber seems to decrease with the reduction in the frequency of tapping. The increase in stimulation frequency did not have a significant effect on production when tapping was performed every 4 days (treatments 3 and 4). Similarly, the passage of tapping frequencies every 4 days to every 5 days (treatments 4 and 5) for the same stimulation frequency $(8 / y)$ did not have a significant impact on production.

Clone PB 330. Rubber production expressed in $\mathrm{kg} \cdot \mathrm{ha}^{-1} \cdot \mathrm{y}^{-1}$ did not distinguish latex harvesting technologies (Table 2). Treatment 4 (d4-8/y), at $50 \%$ tapping intensity, was the highest $\left(2166 \mathrm{~kg} \cdot \mathrm{ha}^{-1} \cdot \mathrm{y}^{-1}\right.$ ) and statistically identical to that of the other treatments. The annual average production of dry rubber per hectare (tapping downward), with all latex harvesting technologies, reached $2049 \mathrm{~kg} \cdot \mathrm{ha}^{-1} \cdot \mathrm{y}^{-1}$. This production has not been influenced by latex harvesting technologies applied to trees.

The average annual yield of dry rubber, all latex harvesting technologies and all clones combined, reached $2310 \mathrm{~kg} \cdot \mathrm{ha}^{-1} \cdot \mathrm{y}^{-1}$. This good yield did not distinguish latex harvesting technologies (Table 2). Regardless of the latex harvesting system or technology applied, the clones IRCA 18 and PB 260 were the most productive, followed by the clone IRCA 130. The clones PB 235 and PB 330 recorded the same and lowest rubber yields.

Table 2: Annual average of dry rubber production expressed in $\mathrm{kg} \cdot \mathrm{ha}^{-1} \cdot \mathrm{y}^{-1}$ in tapping downward of clones PB 235, IRCA 18, IRCA 130, PB 260 and PB 330 for nine years in the south-west of Côte d'Ivoire

\begin{tabular}{|c|c|c|c|c|c|c|}
\hline \multirow{2}{*}{ Treatments } & \multicolumn{6}{|c|}{ Dry rubber production $\left(\mathrm{kg} \cdot \mathrm{ha}^{-1} \cdot \mathrm{y}^{-1}\right)$} \\
\hline & PB 235 & IRCA 18 & IRCA 130 & PB 260 & PB 330 & Mean \\
\hline $\mathrm{S} / 2 \mathrm{~d} 26 \mathrm{~d} / 7$ nil stimulation & 2061 a & $2594 \mathrm{a}$ & $2188 \mathrm{a}$ & $2819 \mathrm{a}$ & $2045 \mathrm{a}$ & $2341 \mathrm{~A}$ \\
\hline $\begin{array}{c}\mathrm{S} / 2 \mathrm{~d} 3 \mathrm{6d} / 7 \mathrm{ET} 2.5 \% \\
\mathrm{~Pa} 1(1) 4 / \mathrm{y}\end{array}$ & $2023 \mathrm{a}$ & $2730 \mathrm{a}$ & $2314 \mathrm{a}$ & 2829 a & 2046 a & $2388 \mathrm{~A}$ \\
\hline $\begin{array}{c}\mathrm{S} / 2 \mathrm{~d} 4 \mathrm{6d} / 7 \mathrm{ET} 2.5 \% \\
\mathrm{~Pa} 1(1) 4 / \mathrm{y}\end{array}$ & 1929 a & 2629 a & 2411 a & $2583 \mathrm{a}$ & $2064 \mathrm{a}$ & $2363 \mathrm{~A}$ \\
\hline $\begin{array}{c}\mathrm{S} / 2 \mathrm{~d} 4 \mathrm{6d} / 7 \mathrm{ET} 2.5 \% \\
\mathrm{~Pa} 1(1) 8 / \mathrm{y}\end{array}$ & $1910 \mathrm{a}$ & $2638 \mathrm{a}$ & $2319 \mathrm{a}$ & $2720 \mathrm{a}$ & $2166 \mathrm{a}$ & $2350 \mathrm{~A}$ \\
\hline $\begin{array}{c}\mathrm{S} / 2 \mathrm{~d} 5 \mathrm{6d} / 7 \mathrm{ET} 2.5 \% \\
\mathrm{~Pa} 1(1) 8 / \mathrm{y}\end{array}$ & 1907 a & $2433 \mathrm{ab}$ & 2365 a & $2665 \mathrm{a}$ & $2012 \mathrm{a}$ & $2276 \mathrm{~A}$ \\
\hline $\begin{array}{c}\mathrm{S} / 2 \mathrm{~d} 6 \text { 6d/7 ET2.5\% } \\
\mathrm{Pa}(1) \text { 10/y }\end{array}$ & $1856 \mathrm{a}$ & $2352 \mathrm{~b}$ & 2363 a & $2459 \mathrm{a}$ & 1964 a & $2239 \mathrm{~A}$ \\
\hline Mean & $1931 \mathrm{C}$ & $2546 \mathrm{~A}$ & $2360 \mathrm{~B}$ & $2662 \mathrm{~A}$ & $2049 \mathrm{C}$ & 2310 \\
\hline
\end{tabular}

In each column, the values assigned to the same letter are not significantly different (Student Newman-Keuls test at $5 \%$ ).

On the whole, the results show that, regardless of the treatment, the production is higher than the ivorian national average $\left(\geq 1800 \mathrm{~kg} \cdot \mathrm{ha}^{-1} \cdot \mathrm{an}^{-1}\right)$ which is one of the best in the world. The rubber production expressed in $\mathrm{kg}$.ha ${ }^{1}$ an $^{-1}$ is overall statistically identical regardless of the technology of harvesting 
the latex and the clone. This result shows that the control (not stimulated) is equivalent to other latex harvesting technologies that are stimulated. This situation is observable at the level of all the different clones of our study and independently of the frequency of tapping. This is due to the fact that tapping produces an activating effect of the rubber production metabolism, as noted by Obouayeba et al. (1996) and Atsin et al. (2016). Indeed, tapping, by the stress it induces, activates the metabolism as well as hormonal stimulation by ethylene production (Chrestin, 1985; Atsin et al. 2016).

At the agronomic level, the clones PB 260 and IRCA 130 express more economic interest than the other clones, in particular clones PB 235 and PB 330. This difference in economic interest could be explained by the low sensitivity to the tapping panel dryness syndrome of the clones PB 260 and IRCA 130, or to the faculty of these clones to respond favorably to stimulation. Indeed, tapping panel dryness syndrome, being a clone-dependent tree reaction (Dian et al. 1995; Gohet, 1996; Okoma, 2008; Diarassouba, 2013), can contribute to the reduction of the yield of a plantation of up to $30 \%$ (Okoma et al. 2011). This is partly responsible for the fact that clone PB 235, which exhibits the highest tapping panel dryness rate, expresses the lowest rubber yield. Moreover, for Koffi (1995) and Gohet (1996), clones that do not respond favorably to stimulation, relative to others, may be considered to have certain intrinsic dispositions that allow them to respond. These provisions seem to be the availability of intrinsic energy (Lacote et al. 2010) conferring on these clones the ability to activate their metabolism to the absence of hormonal stimulation. The metabolism of clones exhibiting such abilities can be considered as easily enabled (Serres et al. 1988).

\section{Influence of Latex Harvesting Technologies on the Radial Vegetative Growth of Clones PB 235, IRCA 18, IRCA 130, PB 260 and PB 330}

Mean annual increments in tree circumference of clones PB 235, IRCA 18, PB 260, IRCA 130 and PB 330, in terms of latex harvesting technologies, fluctuated between 2.7 and $3 \mathrm{~cm} \cdot \mathrm{y}^{-1}$. They are statistically in the same order regardless of the treatment (Table 3). For all latex harvesting technologies and all clones together, the average annual tree circumference increase was $2.9 \mathrm{~cm}$.

The average annual tree circumference of clones PB 235 was statistically highest $\left(3.7 \mathrm{~cm} \cdot \mathrm{y}^{-1}\right)$, followed by PB $330\left(2.9 \mathrm{~cm} . \mathrm{y}^{-1}\right)$ and IRCA $130\left(2.7 \mathrm{~cm}^{-\mathrm{y}^{-1}}\right)$ which are statistically identical to one another. The clones IRCA 18 and PB 260 show the mean annual tree circumference increases of the most statistically small trees. 
Table 3 : Mean values of tree trunk circumference (cm.y-1) in clones PB 235, IRCA 18, IRCA 130, PB 260 and PB 330 in bleeding from treatment for nine years in the southwest Côte d'Ivoire

\begin{tabular}{|c|c|c|c|c|c|c|}
\hline \multirow{2}{*}{ Treatments } & \multicolumn{6}{|c|}{ Tree trunk circumference growth $\left(\mathrm{cm} \cdot \mathrm{y}^{-1}\right)$} \\
\hline & PB 235 & IRCA 18 & IRCA 130 & PB 260 & IRCA 330 & Mean \\
\hline $\mathrm{S} / 2 \mathrm{~d} 26 \mathrm{~d} / 7$ nil stimulation & $3,5 \mathrm{a}$ & $2,9 \mathrm{a}$ & $2,8 \mathrm{a}$ & $2,7 \mathrm{a}$ & $3,0 \mathrm{a}$ & $3,1 \mathrm{~A}$ \\
\hline $\mathrm{S} / 2 \mathrm{~d} 36 \mathrm{~d} / 7 \mathrm{ET} 2.5 \% \mathrm{~Pa} 1(1)$ & $3,7 \mathrm{a}$ & $2,4 \mathrm{a}$ & $2,7 \mathrm{a}$ & $2,3 \mathrm{a}$ & 2,9 a & $2,9 \mathrm{~A}$ \\
\hline $\mathrm{S} / 2 \mathrm{~d} 4$ 6d/7 ET2.5\% Pa1(1) & 3,9 a & $2,3 \mathrm{a}$ & $2,6 \mathrm{a}$ & $2,6 \mathrm{a}$ & 2,8 a & $2,9 \mathrm{~A}$ \\
\hline $\begin{array}{c}\mathrm{S} / 2 \mathrm{~d} 4 \text { 6d/7 ET2.5\% Pa1(1) } \\
8 / \mathrm{y}\end{array}$ & $3,8 \mathrm{a}$ & $2,3 \mathrm{a}$ & $2,7 \mathrm{a}$ & $2,5 \mathrm{a}$ & 2,9 a & $2,9 \mathrm{~A}$ \\
\hline $\begin{array}{c}\mathrm{S} / 2 \mathrm{~d} 5 \text { 6d/7 } \underset{8 / \mathrm{yT}}{\mathrm{ET}} .5 \% \mathrm{~Pa} 1(1) \\
\end{array}$ & $3,6 \mathrm{a}$ & $2,1 \mathrm{a}$ & $2,7 \mathrm{a}$ & $2,5 \mathrm{a}$ & $2,8 \mathrm{a}$ & $2,8 \mathrm{~A}$ \\
\hline $\begin{array}{c}\mathrm{S} / 2 \mathrm{~d} 6 \text { 6d/7 ET2.5\% Pa1(1) } \\
10 / \mathrm{y}\end{array}$ & $3,8 \mathrm{a}$ & $2,1 \mathrm{a}$ & 2,9 a & $2,5 \mathrm{a}$ & 2,9 a & $2,9 \mathrm{~A}$ \\
\hline Mean & $3,7 \mathrm{~A}$ & $2,4 \mathrm{C}$ & $2,7 \mathrm{~B}$ & $2,5 \mathrm{C}$ & $2,9 \mathrm{~B}$ & 2,9 \\
\hline
\end{tabular}

In each column, the values assigned to the same letter are not significantly different (Student Newman-Keuls test at 5\%

The average annual tree circumference increment, all latex harvesting technologies and all clones combined is $2.9 \mathrm{~cm}$. This average annual increase in circumference is good and consistent with that of clones with strong vegetative growth as the work of Obouayeba \& Boa (1993) then Obouayeba et al. (2009) have indicated. This is particularly true since the yield of all clones and latex harvesting technologies combined reaches $2310 \mathrm{~kg} / \mathrm{ha} / \mathrm{year}$, as against 1903 obtained from the clone IRCA 111 (Obouayeba et al. 2009). This level of increase is explained by the activation of the function of rubber production by hormonal stimulation causes an increase in the energy requirements, as well as assimilates (minerals, enzymes and organic elements) necessary for the synthesis of latex constituents, and therefore of rubber production (Gohet, 1996; Lacote et al. 2010).

In the face of these increased needs, the rubber plant, the laticiferous cell (Jacob et al. 1995) is obliged to use its reserves in the event of a shortage of assimilates (Jacob et al. 1988). The immediate consequence of this action is the reduction of vegetative growth (Obouayeba, 2005; Gohet, 1996). For this purpose, the clones possessing the strongest laticiferous wells, that is to say, exhibiting the highest intralaticiferous sucrose contents at a production level or an activation of the analogous metabolism, could be those for which the antagonism between growth and production is weakest and vice versa (Gohet, 1996).

Isoprene biosynthesis would then have less influence on vegetative growth than the flow of available assimilates for this biosynthesis is important. 
Logically, it seems that a high production potential can limit the availability of laticiferous sugar and therefore the strength of the laticigene well by competition for photosynthesis (Gohet, 1996). Our results on the yield of rubber and vegetative growth express the fact that the more the tree produces rubber, the less it develops as Diarrassouba et al. (2012), Obouayeba et al. (2002) and Obouayeba (2005) have pointed out. However, the depressive effect of hormonal stimulation on vegetative growth is attenuated by the reduction in tapping intensity, as the latter induces stress on the tree, which can play a stimulating role hormonal stimulation (Chrestin, 1985). This is why the trees of the treatment S/2 d6 6d/7 ET2.5\% Pa1(1) 10/y have radically vegetative growth statistically equal to that of the unstimulated rubber trees.

\section{Influence of Latex Harvesting Technologies on Tapping Panel Dryness Sensitivity of Clones PB 235, IRCA 18, IRCA 130, PB 260 and PB 330}

Clone $P B$ 235. The mean rate of tapping panel dryness, all technologies combined, reached a high level $(8.4 \%$, Table 4). Treatment 1 (d2-nil stim), with $100 \%$ tapping intensity, recorded the highest rate $(12 \%)$. This rate is statistically equivalent to those of $2(\mathrm{~d} 3-4 / \mathrm{y})$ and $4(\mathrm{~d} 4-8 / \mathrm{y})$, and statistically higher than the $3(\mathrm{~d} 4-4 / \mathrm{y}), 5(\mathrm{~d} 5-8 / \mathrm{y})$ and $6(\mathrm{~d} 6-10 / \mathrm{y})$ which displayed the lowest and identical tapping panel dryness ratios. The change from 4 to 8 annual stimulations for the same tapping frequency $(\mathrm{d} 4)$ resulted in a slight increase in the tapping panel dryness rate (d4-4/y: $7.3 \%, \mathrm{~d} 4-8 / \mathrm{y}: 8,8 \%)$. On the other hand, reducing the tapping frequency from d4 to $\mathrm{d} 5$ for the same stimulation frequency $(8 / y)$, resulted in a relatively less tapping panel dryness rate $(\mathrm{d} 4-8 / \mathrm{y}: 8.8 \%, \mathrm{~d} 5-8 / \mathrm{y}: 7.0 \%)$.

IRCA clone 18. The mean tapping panel dryness rate for all technologies was $4.4 \%$ (Table 4). This rate is average and shows overall a technology effect of latex harvesting. Treatment 1 trees, the most tapped, showed the highest dry rate $(8.9 \%)$. This high rate is statistically higher than those of the $2(\mathrm{~d} 3-4 / \mathrm{y})$ and $4(\mathrm{~d} 4-8 / \mathrm{y})$ patterns, which are also statistically higher than the $5(\mathrm{~d} 5-8 / \mathrm{y})$ and $6(\mathrm{~d} 6-10 / \mathrm{y})$ that displayed the lowest and identical tapping panel dryness rates.

IRCA clone 130. The average rate of tapping panel dryness of all technologies combined was worth $7.2 \%$ (Table 4). This rate is high, with the exception of treatment $3(\mathrm{~d} 4-4 / y)$, which is tapped every four days, and the rate is lower than that tapped at the same frequency but at a double frequency of hormonal stimulation,effect technology of latex harvesting, including an effect of tapping intensity.The tapping panel dryness rate increases overall with the intensity of tapping. Latex harvesting technology that results in the highest tapping panel dryness rate of the six treatments is pattern 1 (d2-nil stim) with the most commonly tapping trees $(10.2 \%)$, while trees treatment $6(\mathrm{~d} 6-10 / \mathrm{y})$ had the lowest rates $(4.5 \%)$. The increase in the number of stimulations in $\mathrm{d} 4$ 
(from 4 to $8 / y$ ) leads to a significant increase in the tapping panel dryness rate (d4-4/y: $5.9 \%$ and d4-8/y: 7.7\%). On the other hand, for the same level of stimulation (treatment $2(\mathrm{~d} 3-4 / \mathrm{y})$ and treatment $3(\mathrm{~d} 4-4 / \mathrm{y})$ then treatment 4 $(\mathrm{d} 4-8 / \mathrm{y})$ and treatment $5(\mathrm{~d} 5-8 / \mathrm{y}))$, the tapping panel dryness is higher in rubber trees tapped at high frequency $(\mathrm{d} 3-4 / \mathrm{y}: 9.7 \%$ and $\mathrm{d} 4-4 / \mathrm{y}: 5.9 \%$; $\mathrm{d} 4-8 / \mathrm{y}$ : 7.7\% and $\mathrm{d} 5-8 / \mathrm{y}: 5.3 \%$ ).

Clone $P B$ 260. The average rate of tapping panel dryness of all technologies combined is $2.2 \%$ (Table 4). This rate is low because it is well below $5 \%$, considered as a threshold in practice. It fluctuates significantly with latex harvesting technology. The latex harvesting technology that results in the highest tapping panel dryness rate of the six treatments is pattern $1(\mathrm{~d} 2-n i l$ stimulation) with the most frequently tapped (3.9\%), while the trees treatment $6(\mathrm{~d} 6-10 / \mathrm{y})$ had the lowest rates $(1.5 \%)$. The increase in the number of stimulations in $\mathrm{d} 4$ (from 4 to $8 / \mathrm{y}$ ) leads to an increase in the tapping panel dryness rate $(\mathrm{d} 4-4 / \mathrm{y}: 1.8 \%$ and $\mathrm{d} 4-8 / \mathrm{y}: 2.6 \%)$. For the same level of stimulation (treatment $2: \mathrm{d} 3-4 / \mathrm{y}$ and treatment $3: \mathrm{d} 4-4 / \mathrm{y}$ then treatment $4: \mathrm{d} 4-$ 8/y and treatment 5: $\mathrm{d} 5-8 / \mathrm{y})$, the $\mathrm{d}(\mathrm{d} 3-4 / \mathrm{y}: 2.5 \%$ and $\mathrm{d} 4-4 / \mathrm{y}: 1.8 \%, \mathrm{~d} 4-8 / \mathrm{y}$ : $2.6 \%$, and $\mathrm{d} 5-8 / \mathrm{y}: 0.8 \%$ ).

Clone $P B$ 330. The mean rate of tapping panel dryness for all technologies combined is $2.4 \%$ (Table 4). This rate is low because it is well below 5\%. It fluctuates with latex harvesting technology. The latex harvesting technology that results in the highest tapping panel dryness rate of the six treatments is treatment 1 (d2-nil stim) where the trees are most tapped $(4.3 \%)$, while processing trees $3(\mathrm{~d} 4-4 / \mathrm{y})$ have the lowest rates $(1.2 \%)$. The increase in the number of stimulations in $\mathrm{d} 4$ (from 4 to $8 / \mathrm{y}$ ) leads to an increase in the tapping panel dryness rate (d4-4/y: $1.2 \%$ and d4-8/y: 3.9\%). For the same level of stimulation (treatment $2: \mathrm{d} 3-4 / \mathrm{y}$ and treatment $3: \mathrm{d} 4-4 / \mathrm{y}$ then treatment 4: $\mathrm{d} 4-8 / \mathrm{y}$ and treatment $5: \mathrm{d} 5-8 / \mathrm{y})$, the $\mathrm{d}(\mathrm{d} 3-4 / \mathrm{y}: 1.5 \%$ and $\mathrm{d} 4-4 / \mathrm{y}: 1.2 \%, \mathrm{~d} 4-$ 8/y: $3.9 \%$, and $\mathrm{d} 5-8 / \mathrm{y}: 1.7 \%$ ).

Overall, in the tapping downward, the mean tapping panel dryness rate of the trees of clones PB 235, IRCA 18, IRCA 130, PB 260 and PB 330, all latex harvesting technologies, was $4.9 \%$. (Table 4). Overall, this average rate increased with the intensity of latex harvesting technology. Treatment without hormonal stimulation, with $100 \%$ tapping intensity, expressed the highest rate (7.9\%). This high rate is followed by those of treatments $2(\mathrm{~d} 3-4 / \mathrm{y})$ and 4 (d4$8 / y)$ which are statistically similar to each other. The lowest tapping panel dryness rates are displayed by treatments 3 (d4-4/y), 5 (d5-8/y) and 6 (d6$10 / y)$. They are statistically identical. The change from 4 to 8 annual stimulations for the same tapping frequency $(\mathrm{d} 4)$ resulted in an increase in the tapping panel dryness rate (d4-4/y: 3.9\% and d4-8/y: $5.6 \%)$. Similarly, at the same level of stimulation (treatment 2: d3-4/y and treatment 3: d4-4/y then treatment 4: d4-8/y and treatment 5: d5-8/y) (d3-4/y: 5.5\% and d4-4/y: $3.9 \%$, 
$\mathrm{d} 4-8 / \mathrm{y}: 5.6 \%$, and $\mathrm{d} 5-8 / \mathrm{y}: 3.5 \%$ ). Compared to clones, PB 235 is most sensitive to tapping panel dryness syndrome, followed by clone IRCA 130. Clones PB 260 and PB 330 exhibit the lowest and statistically identical tapping panel dryness ratios.

Table 4 : Average tapping panel dryness rates of trees in clones PB 235, IRCA 18, IRCA 130, PB 260 and PB 330, in tapping downward, according to treatments for nine years in south-west Côte d'Ivoire

\begin{tabular}{|c|c|c|c|c|c|c|}
\hline \multirow{2}{*}{ Treatments } & \multicolumn{6}{|c|}{ Tapping panel dryness rates $(\%)$} \\
\hline & PB 235 & IRCA 18 & IRCA 130 & PB 260 & PB 330 & Mean \\
\hline $\mathrm{S} / 2 \mathrm{~d} 2 \mathrm{6d} / 7$ nil stimulation & $12,0 \mathrm{a}$ & 8,9 a & $10,2 \mathrm{a}$ & $3,9 \mathrm{a}$ & $4,3 \mathrm{a}$ & 7,9 A \\
\hline $\begin{array}{c}\mathrm{S} / 2 \mathrm{~d} 3 \mathrm{6d} / 7 \mathrm{ET} 2.5 \% \mathrm{~Pa}(1) \\
4 / \mathrm{y}\end{array}$ & $9,3 \mathrm{ab}$ & $4,6 \mathrm{~b}$ & $9,7 \mathrm{a}$ & $2,5 \mathrm{~b}$ & $1,5 \mathrm{~b}$ & $5,5 \mathrm{~B}$ \\
\hline $\mathrm{S} / 2 \mathrm{~d} 46 \mathrm{~d} / 7 \mathrm{ET} 2.5 \% \mathrm{~Pa}(1)$ & $7,3 \mathrm{~b}$ & $3,1 \mathrm{bc}$ & $5,9 \mathrm{c}$ & $1,8 \mathrm{c}$ & $1,2 \mathrm{~b}$ & $3,9 \mathrm{C}$ \\
\hline $\begin{array}{c}\mathrm{S} / 2 \mathrm{~d} 46 \mathrm{~d} / 7 \mathrm{ET} 2.5 \% \mathrm{~Pa} 1(1) \\
8 / \mathrm{y}\end{array}$ & $8,8 \mathrm{ab}$ & $5,0 \mathrm{~b}$ & $7,7 \mathrm{~b}$ & $2,6 \mathrm{~b}$ & $3,9 \mathrm{a}$ & $5,6 \mathrm{~B}$ \\
\hline $\begin{array}{c}\mathrm{S} / 2 \mathrm{~d} 5 \text { 6d/7 ET2.5\% Pa1(1) } \\
8 / \mathrm{y}\end{array}$ & $7,0 \mathrm{~b}$ & $2,9 \mathrm{c}$ & $5,3 \mathrm{c}$ & $0,8 \mathrm{~d}$ & $1,7 \mathrm{~b}$ & $3,5 \mathrm{C}$ \\
\hline $\begin{array}{c}\mathrm{S} / 2 \mathrm{~d} 6 \text { 6d/7 ET2.5\% Pa1(1) } \\
10 / \mathrm{y}\end{array}$ & $5,9 \mathrm{~b}$ & $2,0 \mathrm{c}$ & $4,5 \mathrm{e}$ & $1,5 \mathrm{c}$ & $1,5 \mathrm{~b}$ & $3,1 \mathrm{C}$ \\
\hline Mean & $8,4 \mathrm{~A}$ & $4,4 \mathrm{C}$ & $7,2 \mathrm{~B}$ & $2,2 \mathrm{D}$ & $2,4 \mathrm{D}$ & 4,9 \\
\hline
\end{tabular}

In each column, the values assigned to the same letter are not significantly different (Student Newman-Keuls test at 5\%)

The mean tapping panel dryness rate of the trees of the clones PB 235, IRCA 18, IRCA 130, PB 260 and PB 330, all latex harvesting technologies is moderate because it is between 4 and 7 \% (Jacob et al. 1987). This average level is acceptable because generally the clones of this metabolic class are sensitive to the tapping panel dryness (Gohet, 1996). This level of tapping panel drynessis a sign of a very good level of resistance to the tapping panel drynesssyndrome (Jacob et al. 1987). Regardless of the latex harvesting technology and the clone, the tapping panel drynessrate, with the exception of treatment $4(\mathrm{~d} 4-8 / \mathrm{y})$ whose rate increases, decreases with decreased frequency of tapping. This result shows that the reduction of the tapping frequency influences less the sensitivity to the tapping panel dryness. Indeed, the high rate of tapping panel drynessdisplayed by high-intensity systems is probably due to an exacerbation of metabolic activation (overheated and/or overstimulation), leading to a large run-down of the productive process leading to a significant production of rubber and leading to an onset of physiological fatigue which is the cause of the increase in the tapping panel dryness rate (Gohet, 1996; Soumahin, 2010). This situation is not systematic and over all clones since the clones IRCA 18 and PB 260 displaying the highest rubber yields exhibit the lowest tapping panel dryness rates while clone PB 235 with 
the rubber yield the lower the highest tapping panel dryness rates. The low tapping panel dryness rates express a good adaptation of the latex harvesting technologies to the clones studied. The highest level of tapping panel drynesspresented by clone PB 235, although having the lowest rubber yield, is an intrinsic characteristic of this clone (Coulibaly et al. 2011).

\section{Influence of Latex Harvesting Technologies on Physiological Profile of Clones with Active or Rapid Metabolism PB 235, IRCA 18, IRCA 130, PB 260 and IRCA 330}

Clone PB 235. The solids content ratio (Ex.S), all technologies combined, reached a very high level (51.1\%, Table 5). Overall, it seems to increase with the reduction in tapping frequency. This increase in the solids content is independent of the technology of latex harvesting. This clone expressed a low sucrose content (sac) $\left(5.2 \mathrm{mmol}^{-1} \mathrm{l}^{-1}\right)$ which also remained statistically invariant regardless of the latex harvesting technology. Its content of inorganic phosphorus (Pi) $\left(20.2 \mathrm{mmol}^{-1}{ }^{-1}\right)$ is high (Table 5). It decreased slightly with the reduction in tapping frequency. Pattern 1 (d2-nil stim), with $100 \%$ tapping intensity, had the highest content $\left(22.6 \mathrm{mmol}^{-1}\right)$, which is statistically identical to that of the other motifs except for treatment 6 (d6-10/y) which statistically expressed the lowest content $\left(15.9 \mathrm{mmol}^{-1}\right)$.The average content of thiol groups ( $\mathrm{R}-\mathrm{SH})$, with all the latex harvesting technologies, reached a slightly low level $\left(0.53 \mathrm{mmol}^{-1}\right)$. Treatment $1(\mathrm{~d} 2-$ nil stim) was distinguished from the others by its higher content of thiol groups $(0.73$ mmol. $\left.1^{-1}\right)$. The other treatments showed statistically identical grades.

Clone IRCA 18. The average solids content of all latex harvesting technologies reached a very high level (53.8\%, Table 5). Treatment 6 (d6$10 / y)$, with $33 \%$ tapping intensity, recorded the highest rate $(55.8 \%)$, which is statistically identical to that of other treatments except treatment 1 (d2-nil stim) which is the most statistically low (50.9\%). Overall, the solids content increases with the reduction in the tapping frequency compensated by the increase in the hormonal stimulation frequency.For all latex harvesting technologies, the average values of sucrose content $\left(5.7 \mathrm{mmol}^{-1} \mathrm{l}^{-1}\right)$ and thiol groups $\left(0.48 \mathrm{mmol}^{-1}\right)$ are low whereas that of the phosphorus content inorganic (20.1 mmol. $\left.\mathrm{l}^{-1}\right)$ is high. Sucrose and inorganic phosphorus levels remained statistically invariable regardless of latex harvesting technology. Concerning the content of thiol groups, treatment 1 (d2-nil stim) statistically recorded the highest content $\left(0.63 \mathrm{mmol}^{-1}\right)$ relative to that of the other treatments which expressed statistically identical contents.

Clone IRCA 130. The average solids content of all latex harvesting technologies reached a very high level $(50.5 \%$, Table 5). Treatments 6 (d610/y) and 5 (d5-8/y), with 33 and $40 \%$ tapping intensity respectively, recorded the highest rates (d6-10/y: 53.6\%; d5-8/y: 52.7). These statistically identical 
rates are slightly higher than those expressed by treatments 3 and 4, which are also statistically identical. The lowest solids content levels were generated by treatments 1 (d2-nil stim: $47 \%$ ) and 2 (d3-4/y: 48.5\%). Overall, the solids content increases with the reduction in the tapping frequency compensated by the increase in the hormonal stimulation frequency. For all latex harvesting technologies, the average values of sucrose $\left(8.7 \mathrm{mmol}^{-1}\right)$, inorganic phosphorus $\left(26.6 \mathrm{mmol} . \mathrm{l}^{-1}\right)$ and thiol groups $\left(0.6 \mathrm{mmol} . \mathrm{l}^{-1}\right)$ are, respectively, high, very high and moderate. Sucrose and inorganic phosphorus levels remained statistically invariable regardless of latex harvesting technology. On the other hand, that of the thiol groups statistically presents a similarity between the values of treatments 1 and 2 . These last values are superior to those of the other treatments which expressed statistically identical contents between them.

Clone $P B$ 260. The average solids content of all latex harvesting technologies reached a very high level (53.8\%, Table 5). Treatment 6 (d6$10 / y$ ) had the highest rate $(55.5 \%)$. This level expressed by treatment 6 is statistically equivalent to those expressed by treatments 5, 4, 3 and 2 and significantly higher than treatment 1 which is the lowest $(48.9 \%)$. This clone expressed a good sucrose content $\left(6.4 \mathrm{mmol}^{-1}\right)$. This content was statistically invariable regardless of the latex harvesting technology. The content of inorganic phosphorus $\left(22.2 \mathrm{mmol}^{-1} \mathrm{l}^{-1}\right)$ is high (Table 5). Treatment 1 (d2-nil stim), with $100 \%$ tapping intensity, had the highest content $\left(25.7 \mathrm{mmol}^{-1}\right)$, which was higher than that of the other 2, 3, 4 and 5 whose contents are statistically identical. Of all six treatments, only pattern $6(\mathrm{~d} 6-10 / y)$ expressed the most statistically low content $\left(19.4 \mathrm{mmol} . \mathrm{l}^{-1}\right)$. The average content of thiol groups, with all latex harvesting technologies, reached a high level (0.81 mmol. $\left.1^{-1}\right)$. Treatments 1 and 2 show the highest levels of thiol groups. These levels, which are statistically identical to each other, are higher than those of the other treatments which are equivalent to one another.

Clone $P B$ 330.The average solids content of all latex harvesting technologies reached a high level (47.1\%, Table 5). Treatment 6 (d6-10/y) had the highest rate $(52.3 \%)$. This rate is statistically equivalent to those expressed by treatments 5,2 and 1 . They are significantly higher than those reported by treatments $4(\mathrm{~d} 4-8 / \mathrm{y})$ and $3(\mathrm{~d} 4-4 / \mathrm{y})$, which are the lowest and statistically similar. With the exception of treatments 4 and 3 , whose levels are statistically of the same order, the solids content appears to increase overall with the reduction in tapping frequency. The sucrose content $\left(10.9 \mathrm{mmol}^{-1}\right)$ is high. This content was statistically similar regardless of the latex harvesting technology. The inorganic phosphorus content $\left(22.1 \mathrm{mmol}^{-1}\right)$ is high (Table 5). Treatment $4(\mathrm{~d} 4-8 / \mathrm{y})$ had the highest concentration $\left(25 \mathrm{mmol}^{-1}\right)^{-1}$. This level, statistically identical to that of treatments 1,2 and 3 , is slightly above treatment $5(\mathrm{~d} 5-8 / \mathrm{y})$ and significantly different from treatment $6(\mathrm{~d} 6-10 / \mathrm{y})$ 
$\left(18.8 \mathrm{mmol}^{-1}\right)$.The average content of thiol groups, with all latex harvesting technologies, reached a high level $\left(0.81 \mathrm{mmol}^{-1}\right)$. Two treatments groups are noted; the treatment 1 (d2-nil stim) which statistically recorded the highest content $\left(1.01 \mathrm{mmol}^{-1}\right)$ and the other treatments with statistically identical levels among themselves and lower than that of treatment 1.

Table 5 : Annual mean values of the physiological parameters of clones PB 235, IRCA 18, IRCA 130, PB 260 and PB 330, tapping for nine years in south-west Côte d'Ivoire

\begin{tabular}{|c|c|c|c|c|c|c|c|c|}
\hline \multirow[b]{2}{*}{ Treatments } & \multicolumn{4}{|c|}{ PB 235} & \multicolumn{4}{|c|}{ IRCA 18} \\
\hline & $\begin{array}{c}\text { Ex.S } \\
(\%)\end{array}$ & $\begin{array}{c}\mathrm{Sac} \\
\left(\mathrm{mmol}^{-}\right. \\
\left.{ }^{1} .1^{-1}\right) \\
\end{array}$ & $\begin{array}{c}\mathrm{Pi} \\
\left(\mathrm{mmol}^{-}\right. \\
\left.{ }^{1} . \mathrm{l}^{-1}\right)\end{array}$ & $\begin{array}{c}\mathrm{R}-\mathrm{SH} \\
\left(\mathrm{mmol}^{-}\right. \\
\left.{ }^{1} . \mathrm{l}^{-1}\right) \\
\end{array}$ & $\begin{array}{c}\text { Ex.S } \\
(\%)\end{array}$ & $\begin{array}{c}\mathrm{Sac} \\
\left(\mathrm{mmol}^{-}\right. \\
\left.{ }^{1} \cdot \mathrm{l}^{-1}\right) \\
\end{array}$ & $\begin{array}{c}\mathrm{Pi} \\
\left(\mathrm{mmol}^{-}\right. \\
\left.{ }^{1} \cdot \mathrm{l}^{-1}\right) \\
\end{array}$ & $\begin{array}{c}\mathrm{R}-\mathrm{SH} \\
\left(\mathrm{mmol}^{-}\right. \\
\left.{ }^{1} .^{-1}\right) \\
\end{array}$ \\
\hline $\begin{array}{c}\mathrm{d} 2- \\
\text { nilstim }\end{array}$ & 49,9 a & $5,4 \mathrm{a}$ & $22,6 \mathrm{a}$ & $0,73 \mathrm{a}$ & $50,9 \mathrm{~b}$ & $6,40 \mathrm{a}$ & $20,5 \mathrm{a}$ & $0,63 \mathrm{a}$ \\
\hline d3 - 4/y & $50,0 \mathrm{a}$ & $4,7 \mathrm{a}$ & $21,0 \mathrm{ab}$ & $0,55 \mathrm{~b}$ & $52,8 \mathrm{ab}$ & $5,3 \mathrm{a}$ & $21,3 \mathrm{a}$ & $0,40 \mathrm{~b}$ \\
\hline $\mathrm{d} 4-4 / \mathrm{y}$ & $50,1 \mathrm{a}$ & $5,6 \mathrm{a}$ & $20,4 \mathrm{ab}$ & $0,49 \mathrm{~b}$ & $54,1 \mathrm{ab}$ & $6,2 \mathrm{a}$ & $18,8 \mathrm{a}$ & $0,44 \mathrm{~b}$ \\
\hline $\mathrm{d} 4-8 / \mathrm{y}$ & $52,0 \mathrm{a}$ & $5,3 \mathrm{a}$ & $19,9 \mathrm{ab}$ & $0,50 \mathrm{~b}$ & $54,7 \mathrm{ab}$ & $5,5 \mathrm{a}$ & $20,3 \mathrm{a}$ & $0,43 \mathrm{~b}$ \\
\hline d5 - 8/y & $52,9 \mathrm{a}$ & $5,3 \mathrm{a}$ & $21,0 \mathrm{ab}$ & $0,50 \mathrm{~b}$ & $54,3 \mathrm{ab}$ & $5,6 \mathrm{a}$ & $20,8 \mathrm{a}$ & $0,50 \mathrm{~b}$ \\
\hline d6 - 10/y & $51,8 \mathrm{a}$ & $4,7 \mathrm{a}$ & $15,9 \mathrm{~b}$ & $0,42 \mathrm{~b}$ & $55,8 \mathrm{a}$ & $5,2 \mathrm{a}$ & $19,0 \mathrm{a}$ & $0,45 \mathrm{~b}$ \\
\hline Mean & 51,1 & 5,2 & 20,1 & 0,53 & 53,8 & 5,7 & 20,1 & 0,48 \\
\hline
\end{tabular}

In each column, the values assigned to the same letter are not significantly different (Student Newman-Keuls test at 5\%).

Table 5 (Continued): Annual mean values of the physiological parameters of clones PB 235, IRCA 18, IRCA 130, PB 260 and PB 330, tapping for nine years in south-west Côte d'Ivoire

\begin{tabular}{|c|c|c|c|c|c|c|c|c|c|c|c|c|}
\hline \multirow[b]{2}{*}{ Treatments } & \multicolumn{4}{|c|}{ IRCA 130} & \multicolumn{4}{|c|}{ PB 260} & \multicolumn{4}{|c|}{ IRCA 330} \\
\hline & $\begin{array}{l}\text { Ex.S } \\
(\%)\end{array}$ & $\begin{array}{c}\text { Sac } \\
\left(\mathrm{mmol}^{-}\right. \\
\left.{ }^{1} \mathrm{l}^{-1}\right)\end{array}$ & $\begin{array}{c}\mathrm{Pi} \\
\left(\mathrm{mmol}^{-}\right. \\
\left.{ }^{1} \cdot 1^{-1}\right)\end{array}$ & $\begin{array}{c}\mathrm{R}-\mathrm{SH} \\
\left(\mathrm{mmol}^{-}\right. \\
\left.{ }^{1} \cdot \mathrm{l}^{-1}\right)\end{array}$ & $\begin{array}{c}\text { Ex.S } \\
(\%)\end{array}$ & $\begin{array}{c}\mathrm{Sac} \\
\left(\mathrm{mmol}^{-}\right. \\
\left.{ }^{1} \cdot \mathrm{l}^{-1}\right)\end{array}$ & $\begin{array}{c}\mathrm{Pi} \\
\left(\mathrm{mmol}^{-}\right. \\
\left.{ }^{1} \cdot \mathrm{l}^{-1}\right)\end{array}$ & $\begin{array}{c}\mathrm{R}-\mathrm{SH} \\
\left(\mathrm{mmol}^{-}\right. \\
\left.{ }^{1} . \mathrm{l}^{-1}\right)\end{array}$ & $\begin{array}{c}\text { Ex.S } \\
(\%)\end{array}$ & $\begin{array}{c}\mathrm{Sac} \\
\left(\mathrm{mmol}^{-}\right. \\
\left.{ }^{1} \cdot \mathrm{l}^{-1}\right)\end{array}$ & $\begin{array}{c}\mathrm{Pi} \\
\left(\mathrm{mmol}^{-}\right. \\
\left.{ }^{1} \cdot \mathrm{l}^{-1}\right)\end{array}$ & $\begin{array}{c}\mathrm{R}-\mathrm{SH} \\
\left(\mathrm{mmol}^{-1} \cdot \mathrm{l}^{-}\right. \\
1)\end{array}$ \\
\hline $\begin{array}{c}\mathrm{d} 2- \\
\text { nilstim }\end{array}$ & $47,0 \mathrm{~b}$ & $9,0 \mathrm{a}$ & $25,0 \mathrm{a}$ & $0,65 \mathrm{a}$ & $49,8 \mathrm{~b}$ & $7,6 \mathrm{a}$ & $25,7 \mathrm{a}$ & $0,90 \mathrm{a}$ & 47,9 a & $11,7 \mathrm{a}$ & $21,9 \mathrm{a}$ & $1,01 \mathrm{a}$ \\
\hline $\mathrm{d} 3-4 / \mathrm{y}$ & $48,5 \mathrm{~b}$ & $7,8 \mathrm{a}$ & $26,2 \mathrm{a}$ & $0,63 \mathrm{a}$ & $52,4 \mathrm{ab}$ & $5,9 \mathrm{a}$ & $21,3 \mathrm{~b}$ & $0,86 \mathrm{a}$ & $49,2 \mathrm{a}$ & $9,9 \mathrm{a}$ & $24,8 \mathrm{a}$ & 0,80 \\
\hline $\mathrm{d} 4-4 / \mathrm{y}$ & $50,6 \mathrm{ab}$ & $9,5 \mathrm{a}$ & $27,7 \mathrm{a}$ & $0,59 \mathrm{~b}$ & $55,1 \mathrm{a}$ & 6,3 a & $20,9 \mathrm{~b}$ & $0,80 \mathrm{~b}$ & $41,6 \mathrm{~b}$ & $11,7 \mathrm{a}$ & $21,3 \mathrm{a}$ & $0,79 \mathrm{~b}$ \\
\hline $\mathrm{d} 4-8 / \mathrm{y}$ & $50,8 \mathrm{ab}$ & $8,1 \mathrm{a}$ & $27,4 \mathrm{a}$ & $0,57 \mathrm{~b}$ & 54,9 a & $5,5 \mathrm{a}$ & $22,5 \mathrm{~b}$ & $0,78 \mathrm{~b}$ & $41,0 \mathrm{~b}$ & $10,8 \mathrm{a}$ & $25,0 \mathrm{a}$ & $0,86 \mathrm{~b}$ \\
\hline d5 - 8/y & $52,7 \mathrm{a}$ & $8,7 \mathrm{a}$ & 25,9 a & $0,59 \mathrm{~b}$ & 54,9 a & $6,8 \mathrm{a}$ & $23,3 \mathrm{~b}$ & $0,77 \mathrm{~b}$ & $51,3 \mathrm{a}$ & $10,1 \mathrm{a}$ & $20,6 \mathrm{ab}$ & $0,76 \mathrm{~b}$ \\
\hline $\mathrm{d} 6-10 / \mathrm{y}$ & $53,6 \mathrm{a}$ & $8,9 \mathrm{a}$ & $27,5 \mathrm{a}$ & $0,54 \mathrm{~b}$ & $55,5 \mathrm{a}$ & $6,4 \mathrm{a}$ & $19,4 \mathrm{c}$ & $0,79 \mathrm{~b}$ & $52,3 \mathrm{a}$ & $11,6 \mathrm{a}$ & $18,8 \mathrm{~b}$ & $0,66 \mathrm{~b}$ \\
\hline Mean & 50,5 & 8,7 & 26,6 & 0,60 & 53,8 & 6,4 & 22,2 & 0,81 & 47,21 & 10,9 & 22,1 & $0,81 \pm 0,11$ \\
\hline
\end{tabular}

In each column, the values assigned to the same letter are not significantly different (Student Newman-Keuls test at 5\%). 


\section{Synthesis of Physiological Profile and Physiological Index of Clones Rapid Metabolism PB 235, IRCA 18, IRCA 130, PB 260 and PB 330}

On the physiological level, two groups of physiological parameters are noted; the solids content, the levels of which are statistically identical with each other regardless of the treatment and other physiological parameters, in particular sucrose, inorganic phosphorus and thiol groups whose contents have varied according to the treatment (Table 6). Overall, the solids content $(51.3$ $\%)$ is very high, while the contents of sucrose $\left(7 \mathrm{mmol}^{-1}\right)$ and inorganic phosphorus $\left(22.2 \mathrm{mmol} . \mathrm{l}^{-1}\right)$ are average to high. However, the content of thiol groups $\left(0.52 \mathrm{mmol}^{-1}\right)$ is average.

In addition, the latex micro diagnosis made it possible to distinguish two groups of treatments; treatment 1 (d2-nil stim) whose trees show a wellbalanced physiological state and other treatments whose physiological states are fairly well balanced (Table 6). Overall, the latex diagnosis shows that the physiological state of trees, subject to different latex harvesting technologies, is fairly well balanced.

Treatment without hormonal stimulation, with 100\% tapping intensity, expressed the highest physiological index (124.1). This physiological index is followed by those of treatments $2(\mathrm{~d} 3-4 / \mathrm{y})$ and $3(\mathrm{~d} 4-4 / \mathrm{y})$ which are statistically similar (Table 6). The lowest physiological index are displayed by treatments $4(\mathrm{~d} 4-8 / \mathrm{y}), 5(\mathrm{~d} 5-8 / \mathrm{y})$ and 6 (d6-10/y). These last physiological index are statistically identical. The change from 4 to 8 annual stimulations for the same tapping frequency $(\mathrm{d} 4)$ resulted in a decrease in physiological index (d4-4/y: 80.7, d4-8/y: 67.6). For the same level of stimulation (treatment 2: d34/y and treatment 3: d4-4/y then treatment 4: d4-8/y and treatment 5: d5-8/y), the physiological index are statistically identical $(\mathrm{d} 3-4 / \mathrm{y}: 76.2$ and $\mathrm{d} 4-4 / \mathrm{y}$ : 80.7, d4-8/y: 67.6 and d5-8/y: 71.8). In fine, the physiological index, produces average contents of sucrose, inorganic phosphorus and thiol groups, distinguishes three groups of treatments; the first group is the only technology for harvesting unstimulated latex. The second group is that of latex harvesting technologies; tapping every three (3) days and tapping every four (4) days, stimulated four (4) times a year. The third group consists of the last three latex harvesting technologies.

Table 6 : Synthesis of physiological profiles and average values of physiological index of clones PB 235, IRCA 18, IRCA 130, PB 260 and PB 330 in tapping downward during nine years of experimentation with respect to the six latex harvesting systems

\begin{tabular}{ccccccc}
\hline \multirow{2}{*}{$\begin{array}{c}\text { Treatment } \\
\text { s }\end{array}$} & $\begin{array}{c}\text { Ex.S } \\
(\%)\end{array}$ & $\begin{array}{c}\text { Sac. } \\
\left(\begin{array}{c}\text { mmol.1 } \\
1\end{array}\right)\end{array}$ & $\begin{array}{c}\text { Pi. }\left(\begin{array}{c}\text { mmol.1 } \\
1\end{array}\right) \\
\text { d2-nil stim }\end{array}$ & $\begin{array}{c}\text { R-SH. } \\
\left(\begin{array}{c}\text { mmol. } \\
1\end{array}\right.\end{array}$ & $\begin{array}{c}\text { Physiological } \\
\text { profile }\end{array}$ & $\begin{array}{c}\text { Physiologica } \\
1 \text { index }\end{array}$ \\
\hline & 7,9 A & $23,1 \mathrm{~A}$ & $0,68 \mathrm{~A}$ & Balanced & $124,1 \mathrm{~A}$
\end{tabular}




\begin{tabular}{|c|c|c|c|c|c|c|}
\hline d3-4/y & $\begin{array}{c}50,6 \\
\text { A }\end{array}$ & $6,4 \mathrm{~B}$ & $22,9 \mathrm{~A}$ & $0,52 \mathrm{~B}$ & $\begin{array}{l}\text { Enough } \\
\text { balanced }\end{array}$ & $76,2 \mathrm{~B}$ \\
\hline d4-4/y & $\begin{array}{c}50,3 \\
\mathrm{~A}\end{array}$ & $7,4 \mathrm{AB}$ & $21,8 \mathrm{AB}$ & $0,50 \mathrm{~B}$ & $\begin{array}{l}\text { Enough } \\
\text { balanced }\end{array}$ & $80,7 \mathrm{~B}$ \\
\hline $\mathrm{d} 4-8 / \mathrm{y}$ & $\begin{array}{c}50,7 \\
\mathrm{~A}\end{array}$ & $6,0 \mathrm{~B}$ & $23,0 \mathrm{~A}$ & $0,49 \mathrm{~B}$ & $\begin{array}{l}\text { Enough } \\
\text { balanced }\end{array}$ & $67,6 \mathrm{C}$ \\
\hline d5-8/y & $\begin{array}{c}53,2 \\
\mathrm{~A}\end{array}$ & $7,0 \mathrm{AB}$ & $22,3 \mathrm{~A}$ & 0,46 B & $\begin{array}{l}\text { Enough } \\
\text { balanced }\end{array}$ & $71,8 \mathrm{C}$ \\
\hline d6-10/y & $\begin{array}{c}53,8 \\
\mathrm{~A} \\
\end{array}$ & $7,1 \mathrm{AB}$ & $20,1 \mathrm{~B}$ & $0,48 \mathrm{~B}$ & $\begin{array}{c}\text { Enough } \\
\text { balanced }\end{array}$ & $68,5 \mathrm{C}$ \\
\hline Mean & 51,3 & 7,0 & 22,2 & 0,52 & $\begin{array}{l}\text { Enough } \\
\text { balanced }\end{array}$ & 80,8 \\
\hline
\end{tabular}

In each column, the values assigned to the same letter are not significantly different (Student Newman-Keuls test at $5 \%$ ).

\section{Choosing the Best Latex Harvesting Systems for Active Metabolism Clones}

The aim of this study on active metabolic clones (IRCA 18, IRCA 130, PB 235, PB 260 and PB 330) is to determine the best latex harvesting system (s) applied to them. This is based on the physiological and sanitary parameters, in particular sensitivity to the tapping panel dryness.

With respect to agronomic parameters, especially rubber production, all latex harvesting technologies are equivalent. On the other hand, particularly the consumption of bark, the technology of latex harvesting; $(15.6<$ consumption $(\mathrm{cm})<20.3)$ than all other latex harvesting technologies, including weekly tapping $(9.4<$ consumption $(\mathrm{cm})<10.4)$ according to the work of Obouayeba et al. (2009) which, therefore, does not recommend it to practice.

Compared to sensitivity to the tapping panel dryness, trees subjected to latex harvesting technology without hormone stimulation exhibited significantly the highest sensitivity followed by those subjected to tapping technologies every three (3) days and bled every four (4) days and stimulated eight (8) times a year. The lowest sensitivity to the tapping panel drynessis expressed by the tapped trees every four (4) days, stimulated four (4) times a year and those bled once a week. Thus, it appears that latex harvesting technology without hormonal stimulation of production can not be among the best. As regards the physiological parameters, it appears from the synthesis of the physiological profiles that globally two main groups of treatments are noted; the first group is formed by the latex harvesting technology without hormonal stimulation of production, with a well-balanced physiological profile. The second group consists of the five (5) other latex harvesting technologies whose physiological profile is fairly well balanced. The physiological index, produced from contents of sucrose, inorganic phosphorus 
and thiol groups, distinguishes three groups of treatments; the first group is formed by the technology of harvesting unstimulated latex. The second group is latex harvesting technology, tapping every three (3) days and tapping every four (4) days stimulated four (4) times a year. The third group consists of the last three latex harvesting technologies.

Our results show that latex harvesting technology without hormonal stimulation of rubber production is the most interesting relative to its rubber productivity and especially to its physiological profile, expressed by the tapped trees, which is significantly the best of all. However, this technology of latex harvesting presents two prohibitive parameters to its promotion. Indeed, the sensitivity to the tapping panel dryness, expressed by the trees of this treatment, high, even exceeding 5\% tolerable, is a serious handicap to the management of the plantation relative to the availability of the tapping or productive trees. In addition, the bark consumption of latex harvesting technology from one-third to nearly double that of other latex harvesting technologies raises a further problem with respect to the management of rubber production.

These two parameters ultimately constitute an important constraint to the proper management of a plantation. The sensitivity to the tapping panel dryness, affecting the number of productive trees, and therefore the productivity of the plantation in the more or less long term, seriously handicaps the promotion of this latex harvesting technology. It is the same with the consumption of bark, which is the capital of the rubber tree. This parameter negatively affects the management time of a plantation's rubber production by reducing it by one-third to one-half relative to other latex harvesting technologies.

The results of the physiological index, those of bark consumption and above all of the sensitivity to the tapping panel dryness, determine the best latex harvesting technologies to be applied to the active metabolism clones studied, tapping every three (3) and every four (4) days, stimulated four (4) times a year.

\section{Conclusion}

In the first nine years after the opening of the tapping panel, the fast metabolism clones: PB 235, IRCA 18, PB 260, IRCA 130 and PB 330 have good rubber productivity $\left(2310 \mathrm{~kg} \cdot \mathrm{ha}^{-1} \cdot \mathrm{an}^{-1}\right)$ with good radial vegetative growth (2.9 cm.an $\left.{ }^{-1}\right)$, a well-balanced physiological profile and an acceptable sensitivity to the tapping panel dryness (4.9\%). The analysis of the influence of latex harvesting technologies on the agronomic, physiological and sanitary parameters makes it possible to conclude that they are almost all adapted to clones with active or rapid metabolism. However, the physiological index, bark consumption, and sensitivity to the tapping panel drynessdiscriminate 
them sufficiently enough to retain only the latex harvesting technologies "S/2 d3 6d/7 Pa1(1) ET2.5 4/y and S/2 d4 6d/7 Pa1(1) ET2.5 4/y as the best. The latex micro-diagnosis, through the physiological index, played a predominant role in the choice of latex harvesting technologies for active metabolism clones: PB 235, IRCA 18, PB 260, IRCA 130 and PB 330. It contributes the modern and efficient management of rubber plantations.

\section{References:}

1. Ashwell, G. (1957). Colorimetric analysis of sugar. Methods Enzymol., 3,73-105.

2. Atsin GJO, Soumahin EF, Kouakou TH, Elabo AEA, Okoma KM and Obouayeba S: 2016. Agronomic Potential of Some Rubber Tree Clones (Hevea brasiliensis) of the Fast Metabolic Activity Class in the Absence of Hormonal Stimulation in Southwestern of Côte d'Ivoire. Am. J. Exp. Agri., 13 (4): 1-13.

3. Boyne, A.F., \& Ellman, G.I. (1972).A methodology for analysis of tissue sulphydryl components. An. Biochem., 46, 639-653.

4. Chapuset, T. (2001). Description des clones étudiés à grande échelle ; Rapport CNRA-HEVEA n ${ }^{\circ} 01 / 01$ - A- Mai 2001. 36 p.

5. Chrestin, H. (1985). La stimulation à l'éthrel de l'hévéa; jusqu'où ne pas aller trop loin. Caoutch. Plast., 647/648, 75-78.

6. Coulibaly L.F., Diarrassouba M., Obouayeba S., Yapi G.C.V., \& Aké S. (2011). Système d'exploitation en saignée inversée du clone PB 235 d'Heveabrasiliensis en Côte d'Ivoire. Journal of Animal \& Plant Sciences, 9 (2), 1147-1160.

7. D’Auzac, J., Jacob, J.L., \& Chrestin, H. (1989). Physiology of rubber tree latex. Boca Raton, Etats-Unis. CRC Press, 472 p.

8. Dian, K., Sangaré, A., \& Diopoh, J.K. (1995). Evidence for specific variation of protein pattern during tapping panel dryness condition development in Hevea brasiliensis; Plant Science, 105, 207-216.

9. Dian, K. (1997). Tapping Panel Dryness Research : List of questions. Int. Rubb. Res. Dev. Board (IRRDB). 1.

10. Diarrassouba, M., Soumahin, E.F., Coulybaly, L.F., N'guessan, A.E.B., Dick, K.E., Kouame, C., Obouayeba, S., \& Ake, S. (2012). Latex harvesting technologies adapted to clones PB 217 and PR 107 of Hevea brasiliensis Muell. Arg. of the slow metabolism class and to the socio-economic context of Côte d'Ivoire. Int. J. Biosci., 2 (12), 125138.

11. Diarassouba, M. (2013). Systèmes d'exploitation adapté aux clones d'Hevea brasiliensis de classes d'activité modérée et rapide. Thèse de doctorat unique de Physiologie végétale à l'UFR-Biosciences de l'Université de Cocody, Abidjan (Côte d'Ivoire), 173 p. 
12. Eschbach, J.M., Roussel, D., Van De Sype, H., Jacob, J.L., \& D’Auzac, J. (1984).Relationships between yield and clonal physiological characteristics of latex from Hevea brasiliensis. Physiol. Vég., 22, 295304.

13. Gohet, E. (1996). La production de latex par Hevea brasiliensis. Relation avec la croissance. Influences de différents facteurs : Origine clonale, stimulation hormonale, réserves hydrocarbonées. Thèse de doctorat d'université, Université Montpellier II, Sciences et Techniques du Languedoc, France, $343 \mathrm{P}$.

14. Gohet, E., Prévôt, J.C., Eschbach, J.M., Clement, A., \& Jacob J.L. (1996). Clone, croissance et stimulation, facteurs de la production de latex. Plant. Rech. Dev., 3 (1), 30-38.

15. Gomez, J.B. (1982). Anatomy of Hevea and its influence on latex production. MalaysianRubber Research and Board (MRRDB), monograph $\mathrm{n}^{\circ} 7$, Kuala Lumpur, $76 \mathrm{p}$.

16. Jacob, J.L., Eschbach, J.M., Prévôt J.C., Roussel D., Lacrotte R., Chrestin H., \& D’AuzacJ. (1985). Physiological basis for latex diagnosis of the functioning of the laticiferous system in rubber trees. In: Rubb. Res. Inst. Malaysia, ed. Proc. Int. rubb. Conf.. Kuala Lumpur (Malaysie). pp. 101-112.

17. Jacob, J.L., Lacrotte, R., Serres, E., \& Roussel, D. (1987). Les paramètres physiologiques du latex d'Hevea brasiliensis, le diagnostic latex, ses bases et sa mise au point. Ekomafevrier, 1987, 64-74.

18. Jacob, J.L., Serres, E., Prévôt, J.C., Lacrotte, R., Clément-Vidal, A., Eschbach, J.M., \& D’Auzac, J. (1988). Mise au point du diagnostic latex. Agritrop., 12, 97-118.

19. Jacob, J.L, Prévôt J.C., Eschbach, J.M., Lacrotte, R., Serres, E., \& Clément-Vidal, A. (1990). Latex flow, cellular regeneration and yield of Hevea brasiliensis. Influence of hormonal stimulation. In: International congress of plant physiology, New Dehli, Inde 15-20 fév. 1988. Vol. 1, Sinha S.K., Sane P.V, Bhargawa S.C et Agrawal P.K. éd., New Dehli, Inde, Society for Plant Physiology and Biochemistry, pp. 426-433.

20. Jacob, J.L., D’Auzac, J., Prévôt J.C., \& Sérier, J.B. (1995). Une usine à caoutchouc naturel : 1'hévéa. La recherche, 276, 538-545.

21. Koffi, K.E. (1995). Recherche de marqueurs moléculaires de la production utilisables en typologie et en sélection clonales chez hévéa brasiliensis. Thèse de doctorat de 3è cycle, Université Nationale de Côte d'Ivoire, Abidjan, n²15, p 220.

22. Koffi, K.E., Elabo, A.A.E., \& Gnagne, Y.M. (2004). Qualité sélective des paramètres physiologiques dans la sélection précoce de l'hévéa (Hevea brasiliensisMuell Arg.). Agronomie Africaine, 16 (3), 1-10. 
23. Lacote, R., Gabla, O., Obouayeba, S., Eschbach, J.M., Rivano, F., Dian, K., \&Gohet, E. (2010). Long-term effect of ethylene stimulation on the yield on rubber trees is linked to latex cell biochemistry. Field Crops Research 115: $94-98$.

24. Obouayeba, S. (1993). Estimation de la quantité de pâte stimulante appliquée sur Hévéas en fonction de leur circonférence au sud-est de la Côte d'Ivoire. Agronomie Africaine, 5 (1), 25-32.

25. Obouayeba, S., \& Boa, D. (1993). Fréquence et repos annuel de saignée d'Hevea brasiliensis, clone PB 235, dans le sud-est de la Côte d'Ivoire. Cahiers Agricultures, 2(6), 387-393.

26. Obouayeba, S. (1995). Récolte de latex de l'hévéa en milieu non industriel. Document de formation des encadreurs du milieu hévéicole non industriel, Projet Hévéa 5 bis, 32 p.

27. Obouayeba, S., Boa, D., \& Kéli Z.J. (1996). Adéquation entre quantité de Pâte stimulante et production de caoutchouc d'Hevea brasiliensis dans le Sud-est de la Côte d'Ivoire. Tropicultura. 14 (2), 54-58.

28. Obouayeba, S., Boa, D., \& Aké, S. (2000). Critical age bark growth and latex vessel formation as attributes for determination of tapping norms. Indian J. Nat. Rubb. Res., 13 (1 \& 2), 38-45.

29. Obouayeba, S., Boa, D., Aké, S., \& Lacrotte, R. (2002). Influence of age and girth at opening on growth and productivity of Hevea. Indiana Journal of Natural Rubber Research, 15 (1), 66-71.

30. Obouayeba, S. (2005). Contribution à la détermination de la maturité physiologique de l'écorce pour la mise en saignée d'Hevea brasiliensis Müell. Arg. (Euphorbiaceae) : normes d'ouverture. Thèse de doctorat d'université, Université de Cocody, Abidjan, Côte d'Ivoire, 223 P.

31. Obouayeba, S. (2009). Saignée de faible intensité appliquée au clone d'Hevea brasiliensis $\mathrm{PB} 217$ pour palier à une pénurie et/ou une cherté de la main d'œuvre saigneur. Fiche technique, 6 p.

32. Obouayeba, S., Soumahin, E.F., Dobo, M., Lacote, R., Gabla, O. \& Doumbia, A. (2009). Agronomic performance of clone IRCA 111 of Hevea brasiliensis underdifferent frequencies of tapping and stimulation in South-West Côte d'Ivoire. J. Rub. Res., 12 (2), 93-102.

33. Okoma, K.M. (2008). Etude de la sensibilité au syndrome de l'encoche sèche chez HEVEA BRASILIENSIS Müll. Arg. (Euphorbiacaea) Thèse de doctorat d'Université, Université Félix Houphouët-Boigny, Abidjan, Côte d'Ivoire, 170 p.

34. Okoma, K.M., Dian, K., Obouayeba, S., Elabo, A.A.E., \& N'Guetta, A.S.P. (2011). Seasonal variation of tapping panel dryness expression in rubber tree HEVEA BRASILIENSISMüll. Arg. In Côte d'Ivoire. Agric. Biol. J. Nor. Am., 2 (3), 559-569. 
35. Serres, E., Clément-Vidal, A., Prévôt J.C., Jacob J.L., Commère J., Lacrotte, R., \&Eschbach J.M. (1988). Typologie clonale des tissus laticifères chez Hevea brasiliensis. In: J.L. Jacob and J.C. Prévôt (Editors), Exploitation - Physiologie et Amélioration de l'Hevea. IRCA-CIRAD, Montpellier, pp 231-246. Wycherley P.R., 1975. Hevea long flow, adverse partition and storm loses, Plant. Kua. Lump., 51, 6-13.

36. Serres, E., Lacrotte, R., Prévôt J.C., Clément-Vidal, A., Commère J. \& Jacob J.L. (1994). Metabolic aspects of latex regeneration in situ for three Hevea clones. Rubb. Ind. J., 7, 79-84.

37. Soumahin, E.F. (2010). Optimisation des systèmes d'exploitation en hévéaculture par la réduction des intensités de saignées. Thèse de doctorat d'université, Université de Cocody, Abidjan, Côte d'Ivoire, $189 \mathrm{P}$

38. Southorn, W.A. (1969). Latex collection in disposable plastic bags and the use of expanded plastic rainguards. Planters'Bull.,104, 156-82.

39. Taussky, H.H., \&Shorr, E. (1953). A micro colorimetric method for the determination of inorganic phosphorus. J. Biol. Chem., 202, 675685.

40. Tonnelier, M., \& Primôt, L. (1979). La stimulation de la production en latex de l'hévéa. PG/MM, IRCA, 8.

41. Thomas, V., Premakumari, D., Reghu, C.P., Panikkar, A.O.N., \& Saraswathy, A.C.K. (1995). Anatomical and histochimical aspects of bark regeneration in Hevea brasiliensis. Ann. Bot. Comp., 75, 421-426.

42. Traoré, M.S., Dick, E.A., Elabo, A.E.A., Soumahin, E.F., Assi, E.G.M., Atsin, O.G.J., Allé, Y.J., N'Guessan, A.E.B., Kouame, C., \&Obouayeba, S. (2014). Effets de différentes fréquences annuelles de stimulation éthylénique sur les paramètres agrophysiologiques et de sensibilité à l'encoche sèche d'Hevea brasiliensis au sud-est de la Côte d'Ivoire : cas des clones PB 235 et PB 260 de la classe d'activité métabolique rapide. Int. J. Biol. Chem. Sci. 8 (3), 956-974. 